\title{
Gangsters or Gandhians? The Political Sociology of the Maoist Insurgency in India
}

\author{
JONATHAN KENNEDY
}

\section{Introduction}

The character of the Indian state has changed remarkably as a result of the economic reforms that were initiated in the early 1990s. This has been described as an "elite revolt" against the constraints of the dirigiste state by an alliance of business groups and the urban middle classes. ${ }^{1}$ At the same time Maoist insurgents have expanded the areas in which they operate and increased the intensity of their operations, particularly in central and eastern states such as Chhattisgarh, Jharkhand, and Orissa. ${ }^{2}$ In recent years, representatives of the Indian state have made remarkable claims about the strength of the insurgents: former Prime Minister Manmohan Singh has described the insurgency as "the single biggest internal-security challenge ever faced by our country"; 3 according to P. Chidambaram, the erstwhile Union Minister of Home Affairs, the insurgents are "active" in 223 of India's 626 districts; ${ }^{4}$ and his ministry claimed that the insurgents "call the shots" in 40,000 square kilometers of Indian territory - an area the size of Switzerland. ${ }^{5}$ While such statements are very effective at grabbing the attention of interested observers, they leave many unanswered questions. Lay terms such as insurgent activity and calling the shots are used as if it is clear what they mean when, in fact, it is not. Such phrases are, as Durkheim puts it, "a tangle of vague impressions, prejudices, and emotions."6

This article combines a variety of concepts from political sociology with evidence from newspaper reports, ${ }^{7}$ insurgent and state documents, and ethnographic studies in order to analyze the nature of Maoist activities. There are two sections. The first aims to move beyond the prevailing Manichean understanding of the Maoist insurgency in India, which either portrays the insurgents as either gangsters or Gandhians. We show that both insurgent violence and fundraising serve, on the whole, the collective interests of the state building enterprise - that is, to consolidate insurgent control in their base areas - rather than the private interests of individual insurgents. The second section seeks to understand the interaction between the Maoist state builders and the Indian state. It argues that the insurgents undermine and fragment the state's monopoly of the means of violence and administration in areas where they operate: in some areas the Indian state is totally absent, while in others the state forms alliances with the insurgents in order to maintain the semblance of a sovereign and democratic ruler.

(C) Jonathan Kennedy

Jonathan Kennedy is a Research Associate at the Department of Sociology, University of Cambridge, and a Teaching Fellow at the Department of Political Science, University College London. 


\section{Maoist Insurgents as a State Building Enterprise}

\section{Distinguishing Insurgents From Criminals}

The manner in which the insurgents' activities are understood is strongly colored by ideology. ${ }^{8}$ Sundar points out that there are three main perspectives on the Maoist issue. ${ }^{9}$ The dominant liberal or "root causes" perspective understands the insurgency as a reaction to poverty and lack of development. This view largely overlooks the role of the Maoists as a political organization and is not really relevant for the questions that are addressed in this article. The revolutionary perspective of Maoists and their sympathizers view them as self-sacrificing political actors who represent the interests of India's exploited and oppressed untouchable and tribal communities in a just war against the "semi-feudal, semi-colonial” Indian state. ${ }^{10}$ In Arundhati Roy's terminology the combatants are "Gandhians with a Gun." police-dominated Ministry of Home Affairs, present them as self-serving criminals. Chidambaram stated that "Maybe one or two [insurgents] are ideologically motivated but most of them are simply bandits,"12 and the Ministry of Home Affairs took out newspaper advertisements claiming that the insurgents were "nothing but cold-blooded murderers."13

How can we make sense of these polarized and politically motivated perspectives? There have been several insightful ethnographic studies that touch on the nature of insurgents' activities and their interaction with the state. Shah concentrates on the nascent insurgency in Ranchi district, Jharkhand and demonstrates how the insurgents built up their power base by challenging the state's monopoly of the "market of protection."14 Shah argues that, at the local level, the boundaries between the state and the insurgents are blurred as the insurgents and local elites that represent the state cooperate. Suykens analyzes the harvesting of tendu patta-the leaves used to wrap beedi cigarettes - in northern Andhra Pradesh, arguing that the state and the insurgents work together in order to sustain a mutually beneficial "joint extraction regime."15 These studies provide valuable insights into certain aspects of the microdynamics of the insurgency in particular areas, but if we were to generalize from their findings we would get a very distorted view of the insurgency. The picture of cozy cooperation between the state and the insurgents that they espouse, "peace in war" as Suykens puts it or "a theatrical rhetoric of one against the other" in Shah's terms, does not help us understand the very real war between the state and the insurgents in which large numbers of people on either side and "in the middle" have been killed. ${ }^{16}$

The starting point of our analysis is the notion that there is a qualitative difference between insurgents and organized criminals. We subscribe to the argument that insurgency should be conceptualized as a state building enterprise in which the insurgents attempt to build "counter-states." 17 As Kalyvas puts it: "state building is the insurgents' central goal and renders organized and sustained rebellion of the kind that takes place in civil wars fundamentally distinct from phenomena such as banditry, mafias, or social movements." 18 The distinction that Kalyvas draws between insurgency - as a state building enterprise - and organized crime, places him in opposition to Tilly's conceptualization of "war makers and state makers as coercive and self-seeking entrepreneurs." 19 It also differs from Shah who uses this conceptualization 
in her analysis and suggests that "terrorism, banditry, piracy, gangland rivalry and state-making all belong on the same continuum, selling protection." 20 But how can we distinguish between state building insurgents and organized criminals? Insurgents seek to expand their "infrastructural power" - the ability to penetrate society and realize its objectives - as well as their "despotic power" - the ability to impose it will by sheer force, regardless of the preferences of society. ${ }^{21}$ Organized criminals are not concerned with the former. They build political institutions that resemble what Reno refers to as "warlord" or "shadow" states, in which leaders "choose to exercise political control through market channels, rather than pursuing politically risky and materially costly projects of building effective state institutions." ${ }^{22}$ State-building insurgents, on the other hand, aim to exercise political control through political channels by building effective state institutions. ${ }^{23}$ What is more, organized criminals are motivated by personal gain, whereas insurgents do not serve the private interests of its members but the collective interests of a political organization. Similar to traditional or patrimonial institutions, individual interests are pursued through a criminal organization, whereas insurgents are more similar to a bureaucratic institution in which power cannot be used at the discretion of the individual and especially not for private gain. ${ }^{24}$

Are the Maoists organized criminals or insurgents according to this conceptual framework ? $^{25}$ The Communist Party of India (CPI) (Maoist), as well as its predecessors, the Peoples War Group (PWG) and Maoist Communist Centre (MCC), follows an orthodox Maoist strategy. ${ }^{26}$ It rejects parliamentary democracy and its stated aim is to capture political power though Protracted People's War, which entails building up bases areas in the countryside, transforming them into guerrilla and then liberated zones, and eventually encircling the cities. ${ }^{27} \mathrm{~A}$ key aspect of this process is to extend the insurgents' infrastructural power by developing institutions that generate mass support through political education and the provision of collective incentives. Insurgents' governance in base areas, particularly in southern Chhattisgarh where political institutions are strongest, is referred to as Janatana Sarkar (People's Government). This operates through two institutional forms, which perform both belligerent and benevolent functions. ${ }^{28}$ Sanghams (committees) belong to legal front organizations, such as the Dandakaranya Kisan Adivasi Mazdoor Sangham (Dandakaranya Peasant Tribal Worker League) and Rythu Coolie Sangham (Farm Laborers League). ${ }^{29}$ Dalams or dasta (armed guerilla squads) belonging to the People's Liberation Guerrilla Army live separately from the villages. They undertake military operations against the state, use violence to punish real or potential opponents in areas under their control, and back up the sanghams' activities with the credible threat of violence.

\section{Cold-Blooded Murderers or State Builders?}

In an insurgency the militarily weaker non-state actor refuses to directly engage the state and instead follows a strategy of guerrilla warfare. The insurgents' success hinges on the behavior of the local population, who provide them with shelter, food, intelligence and new recruits. ${ }^{30}$ Thus, a crucial issue for the insurgents is to ensure the compliance of local population in order to secure the resources that are essential for fighting guerrilla warfare. Azad, the erstwhile CPI (Maoist) spokesman, points out that "the class struggle at the ground level . . is a struggle for power" in which the "diehard 
reactionaries have to be suppressed, while the rest have to be patiently politicized."31 This echoes Weber's argument that "obedience is determined by highly robust motives of fear and hope." 32 The compliance of the local population can be secured through the provision of benefits. It is widely argued, even by the Indian state, that the insurgents have provided tribal (adivasi) and untouchable (dalit) communities with collective incentives, such as land reforms, better prices for forest produce, improved access to forests, protection from violence by upper castes and state officials, and a sense of self respect that had previously been absent. ${ }^{33}$

Nevertheless, violence or the credible threat of violence plays an important role in the encouraging behavior that is beneficial to the insurgents. We should not, however, fall into the fallacy of seeing such violence as a specific feature of insurgent activity. It is not unusual for either states or state building enterprises to use violence and threats of violence. As Weber points out, violence is "not the normal or sole means used by the state" (or state-building institution) but the relationship between the two "is a particularly intimate one." 34 This might seem like a facile point to political sociologists but it is one that is overlooked by many observers - despite the Indian state's involvement in violent counterinsurgency operations in Kashmir, Punjab, the Northeast and central India and its complicity in violence perpetrated against Muslims, Sikhs, dalits, and adivasis at various points in time. For example, Prakash Singh refers to the Maoist insurgents as terrorists and defines terrorism as "the use of violence towards political ends," therefore failing to acknowledge that the Indian state also use "violence towards political ends." 35

Primarily, the insurgents use violence in areas under their control to punish those they suspect of collaborating with the state and to warn others against this path. Most often the victims of insurgent violence are insurgents-turned-defectors or suspected informers. Frequently this is done through People's Courts (Jan Adalats) that are conducted in front of the public and are designed to both punish the accused and warn those watching against treachery. For example, in Surjuga, Chhattisgarh, in 2001, the insurgents gunned down three suspected defectors in front of journalists, government officials and a large public audience after a public trial that had lasted from 2:30 pm to 7:00 pm. ${ }^{36}$ The decapitated bodies of police informers are often displayed in public with notes describing their crimes and warning others tempted to inform that they will meet the same fate. ${ }^{37}$ There are other reports of suspected informers having their hands or legs chopped off with axes. ${ }^{38}$ In all of these cases the message is clear: if you collaborate with the state, you will be punished with brutal violence. What is more, it is interesting to note that insurgent violence against the inhabitants of areas under their control increases when the insurgents' control of an area is threatened. ${ }^{39}$ In 2010, when the insurgents came under pressure from state forces in West Midnapore, West Bengal, they initiated a drive to "identify and annihilate" police informers and 20 suspected informers were killed in one month. ${ }^{40}$ Similarly, in 2011 every major counterinsurgent operation that took place in Koraput, Orissa, was swiftly followed by the death of a suspected police informer at the hands of the insurgents. ${ }^{41}$

It is apparent that there is a logic to insurgent violence. ${ }^{42}$ Collaborators pose an enormous danger to the insurgents because they may provide information to the state that undermines the insurgents' ability to control an area. They must therefore be 
sanctioned with targeted violence in order to discourage others from following suit. CPI (Maoist) General Secretary Ganapathy makes this point in response to criticism of the insurgents' use of violence against tribal counterinsurgents in southern Chhattisgarh:

Retribution ... is a necessary to control these goons... . In principle, we are against death penalty and our new system that would evolve after the seizure of power will scrap death sentence (sic). But now the oppressed people and the revolutionaries are compelled to resort to it for our defence; after all, our very survival is at stake if proven counter-revolutionaries are allowed to create havoc with people's lives and pass on information about our movements to the police. ${ }^{43}$

This supports the argument that - as Shah who, citing Diego Gambetta, points outinsurgent violence is a "means not an end." 44 Nevertheless, our interpretation differs from Shah's in that we argue, broadly speaking, that the empirical record shows that the end of insurgent violence is political power rather than merely the "markets of protection."

It should, however, be noted that in some situations insurgent violence crosses the blurred boundary between private and collective interests. For example, in the late 1990s there were there were cases of insurgents killing their comrades in order to claim financial rewards from the Andhra Pradesh state government. In 1998, Somla Naik, a member of a PWG guerrilla squad in Nalgonda, shot dead four sleeping comrades, including her commander, in order to claim a 340,000 rupees (6,800 dollars) reward. ${ }^{45}$ Ten days later, Jadalu Nagaraju, another PWG cadre, killed the Karimnagar PWG district committee secretary in order to collect a reward of one million rupees (20,000 dollars), after which he was presented at a press conference beside Andhra Pradesh's Home Minister and Director General of Police. ${ }^{46}$ There are also cases where the insurgents have killed people who have brought their financial interests to public attention. In 2011 Niyamat Ansari, a social activist, was killed by the insurgents after making allegations of corruption against insurgents in Latehar, Jharkhand. ${ }^{47}$ Private interests do not just relate to money. For example, in 2011 in Ranchi, Jharkhand, the CPI (Maoist) shot dead a young computer engineer who was, according to the local police, the boyfriend of a woman who was having an affair with a Maoist area commander. ${ }^{48}$

The Maoist insurgent leaders attempt to dissociate their organization from acts of violence that do not serve their organization's collective interests. CPI (Maoist) politburo member Misir Besra admits that "mistakes have certainly been made-but they were not the decisions of the party. ... If civilians are killed for no reason, we do not think that is right and we also admit our mistakes to say that this will not be repeated." 49 Indeed, on several occasions the insurgents have apologized when members of the public have been erroneously killed. For example, in 2011, the CPI-Maoist's Bihar-Jharkhand-North Chhattisgarh-Uttar Pradesh Regional Committee stated that a "lower level committee" had committed a "mistake" by executing Niyamat Ansari and "apologized" for it. ${ }^{50}$ In 2007 Ganapathy, the CPI (Maoist) General Secretary, apologized for two recent episodes of errant violence that had killed members of marriage 
party and traders in southern Chhattisgarh. He claimed that these incidents "occurred due to mistaken identity" and went on to state: "No revolutionary would ever think of committing such attacks on innocent people." 51

It is interesting to note that government violence in insurgent controlled areas appears to be much more indiscriminate than insurgent violence. State terror reached its zenith in southern Chhattisgarh in the mid-2000s when a state-sponsored counterinsurgent militia, Salwa Judum, burned down houses in scores of villages, raped dozens of women, and killed countless tribal people, resulting in the displacement of over a quarter of a million people. ${ }^{52}$ But state violence still occurs in this area. In 2011 the security forces attacked a village, burnt down 37 houses and raped two women in Dantewara, Chhattisgarh. ${ }^{53}$ In the summer of 2012, the police shot at a group of people who had gathered for a Maoist organized hearing over a land dispute in Bijapur, Chhattisgarh, killing 18 tribal villagers. ${ }^{54}$ This is as Kalyvas would predict: in areas under their control the insurgents have good access to information and can therefore use targeted and effective violence, whereas the state does not and can only resort to indiscriminate and often counterproductive violence. ${ }^{55}$

\section{Bandits or State Builders?}

The insurgents' critics have given various figures for insurgents' annual income in order to support the claim they are bandits, gangsters or mafia. Chhattisgarh Director General of Police Vishwa Ranjan estimates, based on captured cashbooks and other documents, that throughout India the insurgents generate 20 billion rupees (about 400 million dollars) per year. ${ }^{56}$ Other sources suggest that the figure is closer to 15 billion rupees (300 million dollars). ${ }^{57}$ The insurgents resort to various tactics in order to generate their income. Some of these include actions that could be interpreted as banditry. For example, in 2008 CPI (Maoist) activists looted more than 50 million rupees (about 1 million dollars) from an armored van belonging to ICICI Bank that was travelling from Jamshedpur to Ranchi in Jharkhand. ${ }^{58}$ The vast majority of the Maoists' income, however, comes from charging individuals and organizations for carrying out economic activities in areas under their control. As erstwhile Union Home Minister Chidambaram points out, "even a small contractor is compelled to pay protection money to Maoists. You can sympathize (with him) or criticize him, but he is not giving (money) out of love but since he has no other option."59

According to Kishenji, the CPI (Maoist) General Secretary, rural lower classes are expected to "voluntarily" donate two days income per year to the insurgents. ${ }^{60}$ The insurgents also coerce government employees into paying them a proportion of their wages. Dipak Majhi, a primary school teacher in Koraput, Orissa explained: "I deposit Rs 100 [about 2 dollars] every month at a spot in the forest, otherwise they may burn down my house."61 When the plains of Bihar were under insurgent control, landlords paid protection money to the insurgents. As Nununu Sharma, a landlord from Jehanabad, stated in 1988: "We have to protect ourselves against the Naxalites. Either we pay them handsomely or arm ourselves. For peace it is better to pay them." 62

In the hilly forested areas of central India the insurgents control the market for forest produce, especially tendu patta. ${ }^{63}$ Only forest traders that pay approved prices to tribal collectors and pay a levy to the insurgents are permitted to operate. Those that do not, 
as well tribal collectors who cooperate with them, are liable to be violently sanctioned. It is estimated that the sale value of the tend $u$ market controlled by insurgents is worth 5 billion rupees (100 million U.S. dollars) and the insurgents take a cut of between five and ten percent. ${ }^{64}$ The insurgents also take a share of the profits from illicit trade in teak, cannabis, and opium in areas under their control. ${ }^{65}$ They also charge building contractors working on government-funded projects in areas under their control. ${ }^{66}$ Again, those contractors who do not give in to the insurgents' demands face sanctions. For example, in 2009 the insurgents destroyed a construction company's machinery and kidnapped six guards working for them in Jamui, Bihar, after the owner refused to pay protection money. ${ }^{67}$

The most important source of protection money is large industries operating in insurgent controlled areas. As former Home Secretary GK Pillai put it: "Many industries in Maoist areas are forced to buy peace with leftwing extremists due to an insecure environment." 68 This is not a new phenomenon. In the early 1990s the police found documents indicating that Ballarpur Paper Mill in eastern Maharashtra paid five million rupees (100,000 dollars) each year in "taxes" to the insurgents. ${ }^{69}$ This money allowed the paper mill's employees to carry on with their business unhindered. According to the erstwhile District Collector (the chief administrative officer in a district), before the mill paid protection money to the insurgents, "there were numerous complaints by the mill officials and contractors of their goods being destroyed by the Naxalites and their men being beaten up. Now, there are no more complaints." 70

The largest source of income, especially in the mineral rich areas of the tribal belt where the insurgents have expanded over the past twenty years, is the mining industry. ${ }^{71}$ Large companies extract and process iron ore, bauxite and coal in areas of Jharkhand, Chhattisgarh, and Orissa that are under insurgent control. The insurgents have the capacity to severely disrupt these operations. For example, a senior official working for the National Mineral Development Corporation claimed that in 2009 the Bailadila mines in Dantewara, Chhattisgarh lost 4.8 billion rupees (96 million dollars) as a result of Maoist interference that included attacks on railways tracks, trains and strikes: "In 2009-10, dispatch of iron ore was affected for 80 days. We were able to do only 60 percent of normal business." 72 It recently became clear-in part as a result of wikileaks revelations - that ESSAR, an Indian conglomerate that owns mineral processing operations in insurgent controlled areas, regularly pays protection money to the insurgents. ${ }^{73}$ In 2005 ESSAR opened a 267 kilometer pipeline to transport iron ore slurry from Dantewara in Chhattisgarh, through Malkangiri in Orissa, to the port of Vishakhapatnam. The pipeline runs through areas where the Maoist insurgents have a strong presence and was subject to a number of attacks. Vishwa Ranjan, who served as Chhattisgarh's Director General of Police from 2007 until 2011, states that "the company's security officer suggested we raise a battalion that they would fund" but he "turned down the suggestion because a force cannot be raised for a private company." 74 With the Indian state unable to guarantee security, ESSAR cut a deal with the insurgents.

Do these activities, in which the insurgents sell protection to various economic actors operating within areas under their control, indicate that the insurgents are bandits, gangsters or Mafioso, as claimed by their critics? As we previously suggested, 
contra Tilly, there is a qualitative difference between the state building enterprises and organized crime. While the former pursue collective interests - the consolidation of an organization's authority in a particular area-the latter are motivated by private gain, most notably the accumulation of personal wealth. There is no indication that the insurgent leaders have gained financially from their participation in the insurgency. ${ }^{75}$ For the past three or four decades they have slept in rudimentary camps in the jungle or moved between safe houses in urban areas. This is a far cry from the manner in which we might expect mafia godfathers or organized crime bosses to live. What is more, the CPI (Maoist) leaders attempt to legitimize their fundraising activities by explaining that their funds are used for collective rather than private means. Kishenji, the CPI (Maoist) General Secretary, claims in a recent interview: "We collect taxes from the corporates and big bourgeoisie, but it's not any different from the corporate sector funding the political parties. We have a half-yearly audit. Not a single paisa is wasted." 76 It seems unlikely that mafia godfathers or organized crime bosses would feel the need to explain their accounting practices to the media. There is no evidence of "direct, personal interventions into markets, both formally and clandestinely, [by insurgent leaders] to bolster their personal power and private wealth." 77 The insurgents are not "warlords" who attempt to seize control of the means of production, as Reno describes in Africa. Rather, the insurgents act like a bureaucratic state, charging the economic actors a certain fee or levy for undertaking their activities and in return guaranteeing them a secure business environment. ${ }^{78}$

Notwithstanding, as the strength and size of the insurgent organization has increased, the insurgent leaders have experienced problems related to the discipline of cadre at the local level. Misir Besra, a CPI (Maoist) politburo member, recently stated that "local level splits are happening because of corruption-because of money. The self-contradictions are arising because of the stealing of money by people."79 Shah's account of the pursuit of financial self-interest at the local level should be understood in this context. ${ }^{80}$ It should also be noted that this is not dissimilar to local level corruption that is widespread among state officials in India. ${ }^{81}$ On the whole, however, insurgents who want to pursue their own private interests have left the insurgent organization, despite the risk of retribution at the hands of their former colleagues. In Aurangabad, Bihar, the insurgents killed a former colleague for extracting money in the name of their organization in $2010 . .^{82}$ In 2011, it was reported that Nageshwar Ganju, a former Maoist who, according to the police, left the insurgents to lead a group that "was largely involved in extortion, kidnapping and levy collection" was killed by the insurgents on the borders of Hazaribagh and Chatra districts in Jharkhand. ${ }^{83}$ In the same year, the police arrested a former PWG insurgent who was "extorting money from government officials posing as secretary of the Maoist party" in Hyderabad, Andhra Pradesh. ${ }^{84}$ The fact that insurgents leave the Maoist organization in order to pursue their own personal financial interests, in spite of the very real risk of retribution, indicates that opportunities for private wealth accumulation within the CPI (Maoist) are limited.

The phenomenon of fake Maoist gangs - that is, criminal groups that have no connection with the insurgents but extort money in their name-underline the distinction between insurgents who aim to serve collective interests and bandits who are motivated by private gain. Below are three examples that occurred in 2011 in Orissa: seven youths 
were arrested for demanding money from vehicle owners while posing as Maoists in Rayagada district; ${ }^{85}$ in Koraput, a man who falsely claimed to represent the insurgents was arrested for trying to extort money from the owner of a stone crushing unit, threatening "dire consequences" if he did not pay them 20,000 rupees (400 dollars); ${ }^{86}$ and in Jharsuguda district a gang of 12 "fake Maoists", who robbed people in their houses at gunpoint, were arrested. ${ }^{87}$

\section{International Links and Weapons Procurement}

The state has consistently tried to discredit the insurgents by linking them with foreign patrons. As Ganapathy, General Secretary of the CPI (Maoist), laments, “Trying to prove the involvement of a foreign hand in every just and democratic struggle, branding those fighting for the liberation of the oppressed as traitors to the country, is part of the psychological-war of the reactionary rulers" (sic). ${ }^{88}$ If there were strong links between foreign donors and the insurgents it would severely damage the CPI (Maoist)'s claims of legitimacy because their ability to control base areas would not be the product of its internally generated capacity.

When we consider India's neighbors in turn, it is clear that none of them provide the insurgents with material support. Obviously, the insurgents' ideological inspiration comes from China. In the 1960s and 1970s the CPI (Marxist-Leninist), at the time the most prominent Maoist organization in India, used the slogan "China's chairman is our chairman" and they received moral support from China. ${ }^{89}$ Nevertheless, the Chinese government do not assist the contemporary Maoist insurgents. Indeed, erstwhile Union Home Affairs Minister Chidambaram recently informed Parliament: "We have no evidence on reports that China is lending support to" the Maoists. ${ }^{90}$ Pakistan is generally perceived as India's biggest enemy. There have been some half-hearted efforts to link the Maoist insurgents to Pakistan and, specifically, the Inter-Services Intelligence. ${ }^{91}$ There is, however, no evidence to suggest that the insurgents receive support from Pakistan in the same manner that Kashmiri insurgents do. Indeed, it should be noted that areas of affected by Maoist insurgents are in eastern and central India, along the way from the border with Pakistan. Maoists are now a powerful political force in neighboring Nepal. But the Communist Party of Nepal (CPN) (Maoist) does not provide the CPI (Maoist) with assistance. The insurgency in Nepal started in 1996, well after the insurgency in India, and in its early days the Indian insurgents provided their Nepalese comrades with inspiration and support. After the CPN (Maoist)'s victory in 2006, they have sought to distance themselves from the CPI (Maoist) in order to retain good relations with the Indian state. Since then, leading members of the CPI (Maoist) have publicly criticized the CPN (Maoist)'s policies. ${ }^{92}$ There are also suggestions that the insurgents had links with the Tamil Tigers (LTTE) in Sri Lanka, which was strongly influenced by MarxistLeninist ideology. The CPI (Maoist) General Secretary, Ganapathy, states: "there is no relation at all between our party and the LTTE," although he admits that several former Tamil Tigers provided the insurgents with "initial training in the last quarter of the 1980s." "93 This is corroborated by several reports in the early 1990s that the insurgents were being trained in the use of arms and explosives by the LTTE. ${ }^{94}$ Nevertheless, it amounted to little more than initial assistance and the recent expansion of Maoist insurgent activity in India occurred during the demise of the LTTE. 
This issue of external support is most clear in weapons provision. Weapons are a crucial resource in Protracted People's War, but they are not readily available from the local population in the same way that food, shelter, intelligence, and recruits are. The insurgents have some capacity to produce their own weapons. In the past this was limited to what are referred to as "country made" guns, but it is claimed that the insurgents now have the capability to produce more sophisticated arms. ${ }^{95}$ There have been suggestions in the press that some arms have been purchased from the Tamil Tigers, and these are consistent with what is known about the relationship between the LTTE and the Maoists. ${ }^{96}$ It is apparent, however, that the vast majority of weapons used by the insurgents have been looted from the police and paramilitaries during insurgent raids - some of which are motivated by the express desire to appropriate arms and ammunition. A booklet published to mark the People's Liberation Guerrilla Army's tenth anniversary notes the number and type of weapons and ammunition captured in each major attack. ${ }^{97}$ Many of these attacks were reported in the mainstream media. In 2004 the insurgents attacked the district armory, five police stations, and the jail in Koraput, Orissa. In an operation lasting six hours, they had seized 1,000 sophisticated guns and 1,000 other weapons estimated to worth over 500 million rupees (10 million dollars). ${ }^{98}$ In February 2006, the Maoists killed eight paramilitary policemen and looted 14 tonnes of explosives from the Bailadila mines in Dantewara, Chhattisgarh. ${ }^{99}$ In 2008, Maoists killed 13 policemen and looted around 1,200 arms and 100,000 bullets from the Nayagarh police armory in Orissa. ${ }^{100}$ In 2009 the insurgents attacked a mine in Koraput, Orissa, shot 10 police and looted large amounts of explosives and detonators. ${ }^{101}$

It is apparent that the majority of weapons are appropriated-and to a lesser extent produced-by the insurgents rather than donated by foreign supporters. More generally, the insurgency is overwhelmingly a homegrown affair. The insurgents' ability to control areas of India does not come from the support that they receive from outside donors, but from their capacity to generate resources within the areas that they control.

\section{Maoist Insurgency as Dual Sovereignty}

This section considers the effect of the insurgents' state building activities on the Indian state. Weber's famously claimed that the state has a monopoly of the legitimate means of violence in a particular territory. ${ }^{102}$ Thus, a key aspect of statehood in the Weberian conceptualization is exclusivity of jurisdiction - the extent to which the state's decisions can be and are contradicted by another authority. But, Hansen and Stepputat propose that we "abandon sovereignty as an ontological ground of power and order, expressed in law or in enduring ideas of legitimate rule, in favor of a view of sovereignty as a tentative and always emergent form of authority grounded in violence that is performed and designed to generate loyalty, fear, and legitimacy." 103 This is particularly true in many postcolonial societies. State building was not a goal of colonial policy outside of the setter colonies and colonialism gave rise to a situation in which political power was dispersed among many forms of local authority. ${ }^{104}$ Colonial powers aimed to expand their despotic power but not their infrastructural power. ${ }^{105}$ This point is crucial for understanding the nature of weak, corrupt and unrepresentative states in which 
local strongmen occupy prominent positions in the postcolonial world. "Here, multiple, fragile, and contested centers of military might, welfare, and ethno-religious and local loyalties claim sovereignty over people and land-both legal sovereignty as in the legitimate right to govern and de facto sovereignty [i.e., the ability to kill, punish, and discipline with impunity]." 106 Thus, sovereignty is not derived from the ability to carry out various functions of state, the cooperation of the population, and control of natural resources, but from the state's internationally recognized right to exercise control over a territory. ${ }^{107}$ As Jackson points out, many states in the postcolonial world are in fact "quasi states" that rely on external support rather than internal legitimacy for their status. ${ }^{108}$

The Indian state's infrastructural power has historically been very limited in rural areas and political power in these areas was largely in the hands of various forms of local authority. On the plains, where caste-based social structure predominated, many of the functions of the state-such as law and order-were dealt with by upper castes. ${ }^{109}$ Indeed, when the insurgents first started gaining influence on the plains of Bihar in the 1980s, the dominant castes did not turn to the police but instead formed their own private armies or Sena, although it should be noted that the police supported the formation of these militia and in some instances even provided them with training. ${ }^{110}$ This indicates that the state did not have a monopoly over the means of violence. What is more, the hilly, forested areas of central India where tribal communities lived had historically been buffer areas in between princely states. ${ }^{111}$ Tribal communities paid tribute to rulers of the plains, but these regions were largely ungoverned by states. After independence, in order to retain a reasonable semblance of sovereignty, the Congress Party made informal deals with influential local "big men" who controlled "vote banks", used in its original sense to describe the political influence exerted by a notables - often upper caste patrons or tribal headmen-over lower caste and tribal clients. ${ }^{12}$ Suykens is aware of this, noting that "the Naxalites do not really replace the state: the state is simply not present." 113 Shah, however, refers to the "market previously controlled by parts of the local state," but the local state she describes consists of a variety of actors, many of whom are related to former zamindar (colonial tax-collector) families, competing in order gain private benefit from public office. ${ }^{114}$ This resembles what Reno has described in the African context as a warlord or shadow state in which "private uses of state assets and prerogatives created a framework of rule outside formal state institutions, a shadow of state bureaucratic agencies based on personal ties." ${ }^{115}$ It is not a state in which there is a separation of public and private spheres and in which political control is exercised through political channels.

What is more, irregular warfare alters sovereignty in a crucial way because the state's monopoly of violence is broken by the territorially based armed challenge of a state building organization. This leads to a situation in which there is "dual sovereignty." 116 The simplest way to understand the division of sovereignty in such circumstances is to distinguish between zones of incumbent control, where government troops and administrators are able to move safely during the day and at night, zones of insurgent control where the government troops are unable to move safely, and administrators are unable to perform basic functions, and zones in which control is contested. ${ }^{117}$ The concep tualization of the Maoist insurgency as a situation of dual sovereignty is most clearly 
illustrated by the importance attached by both sides to the flying of flags on symbolically important days such as Republic Day or Independence Day. ${ }^{118}$ The insurgents often organize processions and hoist black or red flags in areas under their control. ${ }^{119}$ The state also attempts to assert its authority by raising the national flag in areas of contested sovereignty. In 2011, the Orissa state airlifted ministers in helicopters to insurgent affected areas to hoist the Tricolour during Republic Day celebrations. ${ }^{120}$ On the same day, the Indian Police Service made a big show of flying the Union flag from Rohtas fort, Bihar, which had until recently been a stronghold of the insurgents. ${ }^{121}$

\section{Zones of Insurgent Control and Areas of Contested Sovereignty}

On a day-to-day basis dual sovereignty manifests itself in the state's limited ability to exert its power in areas where the insurgents operate. This point has been made elsewhere. For example, the Ministry of Home Affairs notes the insurgents "supplant the local State machinery and assert hegemony over rural tracks." ${ }^{22}$ Journalist Shubhranshu Choudhary and activist Gautam Navlakha have also argued that the Maoists project state-like control over parts of southern Chhattisgarh. ${ }^{123}$ The consequences of this are, nevertheless, under-theorized in all these accounts. Some areas of India are zones of insurgent control where the state is more or less absent-in other words, where security forces are unable to move safely, and administrators are unable to perform basic functions. The most notable example is an area of 4,000 square kilometers centered on the Abujhmad forest in southern Chhattisgarh. Brigadier (Retired) BK Ponwar, the director of the Counter Terrorism and Jungle Warfare College in Chhattisgarh, recently suggested that it is "a liberated zone and under the total influence of Naxalites." 124 Ponwar pointed out that "there is no police station in the region, and the Naxalites have put up explosives and landmines at all entry routes." After visiting Gadchiroli, a neighboring district in Maharashtra, a Times of India journalist noted that "security forces have avoided visiting these hamlets for long. The villagers could not recall seeing a police search party or an operation in the adjoining jungles in a long time. On the other hand, Naxals have been holding regular meetings with the villagers and also using them for safe shelter with no intelligence leaking from here." 125 Obviously, the police have no capacity to enforce the law in this region, which also includes contiguous areas on the other side of the state borders with Andhra Pradesh and Orissa. For example, in 2011 when the insurgents executed seven men in a People's Courts in the Abujhmad, no First Information Report ${ }^{126}$ was filed because, as the Times of India noted, "the area is out of bounds for the Indian state." ${ }^{27}$ Thus, it is not the state but the insurgents who have exclusivity of jurisdiction in their base areas.

Currently, the only other region in which the insurgents have more or less complete control is parts of West Jharkhand. Several other areas have been under insurgent control at some point over the past three decades, although this is no longer the case. The most notable examples are the plains of Central Bihar until the mid- to late1990s, ${ }^{128}$ parts of northern Telengana in Andhra Pradesh until mid-2000s, ${ }^{129}$ and the Jangal Mahal area of West Bengal until recently. ${ }^{130}$ In the vast majority of areas in which the insurgents are active - the 40,000 square kilometers cited by the Ministry of Home Affairs-sovereignty is contested. 
In other areas the state is not absent, but its security forces are unable to move around safely. There are fortified police stations in parts of southern Chhattisgarh but the fact that the police are unable to move safely beyond their confines demonstrates that the state does not control surrounding areas. In 2011 a Times of India journalist visiting the Kishtaram police station in Dantewara district was told by a resident police officer that they never venture out: "DDo you see that hut?' he says, pointing $100 \mathrm{~m}$ away. 'It is beyond our reach. We cannot go there.' Then, shifting his gaze to the concertina wire and sand bags just $10 \mathrm{~m}$ away, the middle aged policeman continues, 'This is the boundary of our existence."'131 Policemen and their supplies are usually transported between Kishtaram police station and areas of India that are under the state's control by helicopter. The danger that state forces face when moving in the surrounding areas was demonstrated in 2007, when 12 police from a neighboring station were ambushed and killed while they were travelling by road to Kishtaram to rescue five of their colleagues who were suffering from cerebral malaria. ${ }^{132}$

There are various areas in India where the police are unwilling to venture out of their police stations at night or where they will only go out during the day in unmarked vehicles wearing civilian clothing. This was apparent in the killing of Jajati Sahoo, a local politician representing the Biju Janata Dal Party - at the time part of the ruling coalition in the state-in Rayagada, Orissa by the PWG in 2002. ${ }^{133}$ On the night of his death, Sahoo called the police station, which was situated two kilometers from his house, on several occasions. Although the police had new vehicles they did not come, and he was dragged out of his house, shot, and hacked to death. The next day, when the police visited the scene, they arrived in an unmarked taxi wearing plain clothes. In a television interview, the officer in charge of the police station defended his actions, saying that the police had been "instructed by the authorities not to venture out in the night."134 This is not an isolated case. For example, in 2010 in West Midnapore, West Bengal, it was reported that police stations were locked at night and that even if there was a murder the police would not venture out, ${ }^{135}$ and in areas of both southern Chhattisgarh and eastern Maharashtra the insurgents do not use their uniforms and marked vehicles when on patrol. ${ }^{136}$

\section{Law and Order}

An indication of the limits to the Indian state's de facto sovereignty is that it is not always able to keep arrested insurgents in captivity for long. The insurgents have used two main tactics to subvert the state's judicial processes and undermine its capability to punish and discipline whoever it pleases. One is to attack jails and free the prisoners. The most dramatic example of this tactic was in 2005 , when following a gunfight outside the central jail in Jehanabad, Bihar, the insurgents released 389 prisoners. ${ }^{137}$ But this was not an isolated example. In 2006, the insurgents attacked a jail in Gajapati district, Orissa and liberated 50 prisoners in an operation that lasted more than two hours. ${ }^{138}$ In 2007, an imprisoned Maoist “overpowered a jail guard in Dantewada jail in Chhattisgarh, snatched his service weapon, and managed to set free 294 inmates, nearly 110 of who were Maoists or Naxal activists." ${ }^{139}$ In 2009 the insurgents attacked a court in Lakhisarai, Bihar and released Misir Besra, a member of the CPI (Maoist) politburo. ${ }^{140}$ These raids are not just a recent phenomenon, nor are they limited 
to provincial backwaters of India. For example, in 1984, PWG cadres raided the prison wing of Osmania Hospital in Hyderabad and freed their leader Kondapalli Seetharamaiah. ${ }^{141}$

The second tactic is to kidnap various people, often government officials, and to offer to release them in exchange for captive insurgents. There have been several recent high profile cases in Orissa. In April 2012 two Italian tourists - the first non-Indians to be kidnapped by the insurgents - were released in exchange for five Maoists, one of which was the wife of the Orissa state commander. ${ }^{142}$ In February 2011, Maoist leader Ganti Prasadam was freed from Ongole prison in order to secure the release of kidnapped Malkangiri District Collector R Vineel Krishna. ${ }^{143}$ But this strategy is not recent, nor limited to Orissa. In Lalgargh in 2010, when 190 suspected insurgent sympathizers were arrested, 23 of them were soon released to secure the freedom of an abducted police officer ${ }^{144}$. In 1987 the Andhra Pradesh Government released seven People's War Group leaders in exchange for seven kidnapped Indian Administrative Service officers. ${ }^{145}$ These are just some of the more notable examples. Kidnappings have taken place on a regular basis since the mid-1980s, and the manner in which the state is forced to bargain with the insurgents over whom it can and cannot imprison underlines its lack of control in many parts of the country.

\section{Benevolent Functions of the State}

In areas controlled by the insurgents, other state officials are also, on the whole, unable to operate. In December 2011, the Union Minister for Rural Development stated that "In the heart of the country, these two places (west Jharkhand and south Chhattisgarh) are liberated zones. Our officers - be it deputy commissioners, block development officers or anganwadi [neo-natal] workers and health employees-don't venture in these places of Jharkhand and Chhattisgarh."146 Nevertheless, it should be noted that the insurgents undertake various programs that mimic and in many cases surpass the efforts of the state in these areas. Indeed, even the state acknowledges that in areas under insurgent control they have enforced a minimum wage, increased prices for agricultural produce, undertaken land reforms, improved access to forests and worked to reduce caste abuse. ${ }^{147}$ Many of their programs are actually in line with the Constitution of India and other legislation and appear in the "Common Minimum Programme" of the United Progressive Alliance (UPA), until recently the ruling coalition led by the Congress Party. ${ }^{148}$ Nevertheless, due to the strength of vested interests and the state's lack of infrastructural power in many rural areas, the state has been unable to enforce these laws.

In areas where sovereignty is contested, government employees and insurgents sometimes form unexpected alliances. This is one of the main points made by Shah and Suykens. Shah observes that the state-or at least the local elite who enjoy the patronage of the state-and the insurgents "work in tandem" and Suykens notes that they "can be active at the same time, both taking up part of the state space." 149 There are other examples of this phenomenon. In 2011, Lalan Kumar, a Congress politician in Bihar, said that in several districts state-employed workers were taking orders from the insurgents: "Even 10 percent of the recommendations of the MPs and legislators are not being implemented, while all the schemes mooted by Maoists are being adhered 
to." 150 What is more, when the insurgents agree with the state's development program, they can actually be better implemented in areas where the insurgents have influence. Erstwhile Cabinet Secretary KM Chandrasekhar points out the National Rural Employment Guarantee (NREGA) scheme (the government's flagship welfare program that provides guaranteed paid work to the rural poor) is actually more effectively implemented in areas where the Maoists have a stronger influence. ${ }^{151}$ It is apparent that, just as the Indian state does not have a monopoly of the means of coercion in insurgent affected parts of the country, it does not have a monopoly of the means of administration.

\section{The World's Biggest Democracy?}

The Indian state's democratic processes do not function well in areas where the insurgents are active. The Maoist leaders consistently call for elections to be boycotted. For example, a press release before the 2009 elections stated: "Parliament is an instrument of oppression and terror in the hands of the reactionary ruling classes, Boycott the parliamentary election! Advance the people's war to establish organs of genuine people's revolutionary-democratic power!! (sic)."152 At the local level, the insurgents frequently display posters imploring people not to vote. For example, in 2009 the insurgents put up handwritten posters in Garhwa, Jharkhand stating "No vote for Capitalists. No vote for a government that allows police to kill innocent people in fake encounters." 153

The boycotts are backed up by violence and threats of violence. The local population is coerced into not voting. The insurgents threaten to chop off the fingers or hands of those who have the indelible ink marks from having voted. ${ }^{154}$ In areas where the insurgents are active, politicians are often unable to campaign. For example, it was reported that, in the run up to the 2009 election, none of the seven candidates dared to campaign in the Abujhmad forest. Shankar Sodhi, the Congress candidate in southern Chhattisgarh, said: "Campaign in Abujhmad? No way! Everybody knows the situation there." 155 Politicians face similar problems in areas of Jharkhand. In East Singhbum, for example, campaigning is limited to the towns, and when candidates travel through the countryside they try to do so incognito. Pradeep Kumar Balmuchu, and incumbent Member of Parliament and leader of the Indian National Congress in Jharkhand, admitted, "I prefer motorcycle over SUVs [Sports Utility Vehicles] to campaign in my constituency as rebels have much influence in the area and threat to our life is always exists" (sic). ${ }^{156}$ Election days are accompanied by violence in many areasthe insurgents attack and sometimes kidnap election officials and their guards, as well as destroying electronic voting machines and other poll material. For example, on the first day of Parliamentary (Lok Sabha) elections in 2009 the insurgents killed 17 people: five election officials died in a landmine explosion in Rajnandgaon, Chhattisgarh; a bus carrying Border Security Force personnel on election duty was attacked in Latehar, Jharkhand killing nine; and in Gaya, Bihar, two police were shot outside a polling booth, electronic voting machines were stolen, and four election officials were kidnapped. ${ }^{157}$

Voting is severely disrupted in areas where the insurgents are active. During the 2009 elections, the state had to fly election officials in a Mi17 helicopter from the district 
headquarters in Bijapur, Chhattisgarh to Pamed police camp. Seven polling centers that were supposed to be situated in seven different locations over a 25 kilometer radius were all placed in one school building that lay opposite the police camp. In such situations, voting levels are obviously very low: "At Pamed, out of 5,646 voters, just 126 voted, a poll percentage of just 2.23 percent. Unsurprisingly, all 126 voters were those who lived down the lane of the police camp." 158 The situation is similar in parts of Jharkhand and Maharashtra. For example, not a single vote was cast in the Sarju area during the 2009 elections, ${ }^{159}$ and there were also areas of Gadchiroli where the state could not conduct voting. ${ }^{160}$

Nevertheless, for all their proclaimed aversion to parliamentary democracy, there are cases where the insurgents interfere with the functioning of the democratic system in surprising ways. Indeed, the insurgents have cooperated with ruling political parties in various states at various times. In the early 1980s, when Nandamuri Taraka Rama Rao (NTR), the founder of the Telugu Desam Party, was attempting to overthrow Congress hegemony in Andhra Pradesh, he courted the support of the insurgents in Telengana, even referring to them as "patriots" (Desh Bhaktalu). ${ }^{161}$ Again, in the early 1990s the PWG helped the Telugu Desam Party with their campaigning in Telengana. For example, the insurgents would drive candidates around insurgent affected areas. ${ }^{162}$ In Bihar, the erstwhile MCC and then the CPI (Maoist) has consistently been accused of helping the Rashtrya Janata Dal during elections. In both the 1995 and 2004 elections is it alleged that the insurgents only enforced the election boycott in areas where the party was struggling. ${ }^{163}$ The CPI (Maoist) interfered in polls in Jharkhand on behalf of the Jharkhand Mukti Morch and Rashtrya Janata Dal parties in the 2009 election. In areas where the insurgents were close to these parties' candidates, some of who were former insurgents, they stopped other parties from campaigning, kidnapped rival candidates, and even knocked on the doors to campaign for their favored candidates. ${ }^{164}$ Jairam Ramesh, the Union Rural Development Minister, recently stated "that Jharkhand is probably the only place where I fail to draw line between the Maoists and politicians." 165 There is evidence that interference also occurs in Village Council (Gram Panchayat) elections. For example, in Gadchiroli, Mahrarasthra, 582 out of 906 of Gram Panchayat candidates were elected unopposed in 2010, reportedly due to the insurgents intimidating rivals of their preferred candidates. ${ }^{166}$ In the same district in 2012, the insurgents forced several elected Gram Panchayat members that were suspected of corruption to resign. ${ }^{167}$

\section{Conclusions}

This article transcended the prevailing Manichean understanding of the Maoist insurgency in India, which either portrays the insurgents as gangsters or Gandhians. It argues that the insurgency should be conceptualized as a state building enterprise rather than a mafia or social movement. The insurgents' ultimate aim is to seize state power, but in practice they build up counter states. They aim to exercise political control through political channels by building effective state-like institutions, such as dalams/dastars, which extend their infrastructural power. Most often, this occurs in areas where the infrastructural power of the state is weak and political power lies in the 
hands of local forms of authority. We show how the insurgents' fundraising activities and violence, which are often cited by critics as evidence that the insurgents are bandits or cold-blooded murderers, fit into the logic of state building. That is, they are designed to serve collective interests of the insurgent organization - to consolidate insurgent rule in base areas - rather than the private interests of individual insurgents. In practice there is some deviancy at the local level but insurgent leaders condemn this. Thus, while the insurgents are often portrayed as agents of lawlessness and the very antithesis of the state, it can be argued that they actually extend state power into areas where the state was previously weak or non-existent.

A crucial difference between our analysis and other studies that have touched on this subject is the focus. Shah's analysis concentrated on a small part of Ranchi district, Jharkhand and stressed the way in which local level insurgents attempt to dominate the markets of protection. Suykens analyzes the manner in which the state and insurgents cooperate in order to allow the smooth functioning of non-timber forest produce sector in northern Andhra Pradesh. These studies provide valuable insights into the specific aspects of the insurgency that they concentrate on. But, as a result of their narrow focus, they only describe small parts of what the insurgents actually do. This is only really problematic when their findings are over generalized or taken out of context. This article took a broader approach, in terms of both space and time. Although in social reality there is a large extent of local variation in the specific microdynamics of Maoist insurgency there is much to be gained from ignoring "a vast number of trees in order to see the forest." 168 We used a variety of evidence to show that the insurgents are not merely motivated by making money from tendu patta or markets of protection. The insurgents do not "choose to exercise political control through market channels."169 Rather, the generation of income must be understood in the broader context of the insurgents' state building project. In other words, the money raised by the insurgents is not an end in itself, but a means of strengthening their organization and consolidating political power in areas where they operate. There is a large amount of evidence to suggest that the insurgents undertake a variety of "risky and materially costly" political activities aimed at expanding their infrastructural in areas where they operate through education and the provision of collective incentives, such as land reforms. ${ }^{170}$

In areas of India where the insurgents are strongest, democratic processes are totally absent as neither election candidates nor election officials are able to go there. In other areas, where sovereignty is contested, political parties cut deals with the insurgents to buy protection and improve their electoral performance. In order to retain a reasonable semblance of sovereignty the state cooperates with the insurgents in a manner similar to the way the state cooperated with upper class patrons and tribal headmen who controlled vote banks in the decades after independence. According to Weber's definition, the most important aspect of sovereignty relates to a state's exclusive ability to govern its territory. But in the postcolonial world sovereignty is a tentative and emergent form of authority grounded in violence. It is apparent that in some areas where the insurgents operate the Indian state is totally absent, while in other areas it does not have a monopoly of the means of violence or administration. India's claim to sovereignty in these areas is based on its internationally recognized right to govern the territory. In this sense, India, at least in the areas affected by insurgency, resembles 
a "quasi state." Shah argues that the boundaries between the state and the insurgents, in which the former is characterized by "alleged rationality and legitimacy" and the latter by "irrationality and violence," are contested. ${ }^{171}$ The article demonstrates that the role of the state and the insurgents are reversed in certain situations. The fact that the insurgents were the first political organizations to attempt to develop infrastructural power in these areas casts severe doubt on the claim made by the erstwhile Union Home Affairs Minister, Chidambaram, that the Indian state has "a legitimate right to use as much force as necessary to regain control of areas dominated by Maoists.”172

\section{Acknowledgments}

I would like to thank Manali Desai, Lawrence King, and Michael Mann for helpful comments on earlier drafts of this article.

\section{NOTES}

1. Stuart Corbridge, John Harriss, and Craig Jeffrey, India Today: Economy, Politics and Society (Cambridge: Polity Press, 2013).

2. Jonathan Kennedy and Sunil Purushotham, "Beyond Naxalbari: A Comparative Analysis of Maoist Insurgency and Counterinsurgency in Independent India," Comparative Studies in Society and History Vol. 54, No. 4 (October, 2012), pp. 832-62; Jonathan Kennedy and Lawrence King, "Adivasis, Maoists and Insurgency in India," European Journal of Sociology Vol. 54. No. 1 (April, 2013), pp. 1-32.

3. Manmohan Singh, "PM's Speech at the Chief Minister's Meet on Naxalism" (2006). Accessed May 15, 2008 via http://pmindia.nic.in/.

4. P. Chidambaram, "Chidambaram Inaugurates DGPs/IGPs Conference" (2009). Accessed June 15, 2010 via http://www.pib.nic.in.

5. “40,000 sq km Under Naxal Control, Govt Tells House Panel,” Times of India, March 5, 2009.

6. Émile Durkheim, The Rules of Sociological Method (New York: Free Press, 1938), p. 22.

7. The information presented in newspapers articles must be analyzed in terms of context in which they are produced. The concepts, definitions and collection processes used in the production of any data are determined by the purpose they serve and the functions of the organizations that use them. The English language newspapers that are cited in this study - most frequently the Times of India-certainly have a conservative bias. Nevertheless, these newspapers also provide a very useful resource because of their unrivalled coverage over time and across space. Thus, although this article makes wide use of newspaper articles, we do so in a manner that is cognizant of their origins, that makes use of a variety of other sources, including insurgent documents, and that is a long way from replicating a conservative perspective. See Robin Jeffrey, "Media and Maoism," in Robin Jeffrey, Ronojoy Sen, and Pratima Sen, eds., More than Maoism: Politics and Policies of Insurgency in South Asia (New Delhi: Manohar, 2012), pp. 341-45.

8. This is not unique to the insurgency in India. See, for example, the incongruous manner in which Rigoberta Menchú and David Stoll explain motivations for participation in the Guatemalan Civil War, or Jeff Paige and Samuel Popkin's contrasting accounts of the Vietnam War. Elisabeth Burgos-Debray, ed., I, Rigoberta Menchú: An Indian Woman in Guatemala (New York: Verso, 1984); David Stoll, Rigoberta Menchu and the Story of All Poor Guatemalans (Boulder: Westview Press, 1999); Jeffrey Paige, Agrarian Revolution: Social Movements and Export Agriculture in the Underdeveloped World (New York: Free Press, 1975); Samuel Popkin, The Rational Peasant: The Political Economy of Rural Society in Vietnam (Berkeley: University of California Press, 1979).

9. Nandini Sundar, "Insurgency, Counter-insurgency, and Democracy in Central India," in Robin Jeffrey, Ronojoy Sen, and Pratima Sen, eds., More than Maoism: Politics and Policies of Insurgency in South Asia (New Delhi: Manohar, 2013), pp. 149-68.

10. CPI (Maoist), “CPI Maoist Programme," (Central Committee [Provisional] Pamphlet, September 21, 2004); CPI (Maoist), Unprecedented Rise in Dalit Atrocities and the Revolutionary Answer (Kolkata: New Vista Publications, 2004); CPI (Maoist), Masses of Dandakaranya Rebel: In the Path of Liberation (Kolkata: Radical Publications, 2005).

11. Arundhati Roy, "Walking With The Comrades," Outlook India, March 29, 2010.

12. "Naxals Not Motivated by Ideology, They're Bandits: Chidambaram," Times of India, April 18, 2009.

13. "Govt Ad Blitz to Counter Naxals on Their Turf." Times of India, September 21, 2009.

14. Alpa Shah, "Markets of Protection: The "Terrorist" Maoist Communist Centre and the State in Jharkhand, India," Critique of Anthropology Vol. 26, No. 3 (September, 2006), pp. 297-314. 
15. Bert Suykens, "Diffuse Authority in the Beedi Commodity Chain: Naxalite and State Governance in Tribal Telengana, India," Development and Change Vol. 41, No. 1 (January, 2010), pp.153-78.

16. Suykens, "Diffuse Authority," p.160; Shah, "Markets of Protection," p.311. In recent years the insurgents have undertaken a several notable attacks on government forces. For example, in April 2010 a group of paramilitary police was ambushed in Dantewara, Chhattisgarh, resulting in 76 deaths. This was the heaviest loss ever incurred by Indian security forces in a single incident in more than six decades of counterinsurgency. The state's counterinsurgency operations, on the other hand, have killed many insurgents and non-combatants. This is discussed in more detail later in the article. Also see Jonathan Kennedy and Lawrence King, “The Conviction of Binayak Sen,” Lancet Vol. 377, No. 9774 (April, 2011), pp. 1316-17; Jonathan Kennedy and Lawrence King, "Understanding the Conviction of Binayak Sen: Neocolonialism, Political Violence and the Political Economy of Health in Central India," Social Science and Medicine Vol. 72, No. 10 (May, 2011), pp. 1639-42; Kennedy and Purushotham, "Beyond Naxalbari”; Kennedy and King, "Adivasis, Maoists and Insurgency in India."

17. Timothy Wickham Crowley, Exploring Revolution: Essays on Latin American Insurgency and Revolutionary Theory (Armonk and London: M.E. Sharpe, 1991), p. 44; also see Theda Skocpol, "What Makes Peasants Revolutionary?” Comparative Politics Vol. 14, No. 3 (April, 1982), pp. 351-75; Jeff Goodwin and Theda Skocpol, "Explaining Revolutions in the Contemporary Third World," Politics and Society Vol. 17, No. 4 (December, 1989), pp. 489-509.

18. Stathis Kalyvas, The Logic of Violence in Civil War (Cambridge: Cambridge University Press, 2006), p. 218.

19. Charles Tilly, "War Making and State Making as Organized Crime," Bringing the State Back In, Peter B. Evans, Dietrich Rueschemeyer, and Theda Skocpol, eds. (Cambridge: Cambridge University Press, 1985), p. 169.

20. Shah, "Markets of Protection," p. 299.

21. Michael Mann, "The Autonomous Power of the State: Its Origins, Mechanisms and Results," European Journal of Sociology Vol. 25, No. 2 (November, 1984), 185-213.

22. William Reno, "Shadow States and the Political Economy of Civil Wars," in Mats Berdal and David Malone, eds., Greed and Grievance: Economic Agendas in Civil Wars (Boulder: Lynne Reiner, 2000), p. 45; also see William Reno, Warlord Politics and African States (Boulder: Lynne Rienner Publishers, 1999).

23. Reno, Warlord Politics. It should be noted that Tilly does argue elsewhere that building a state depends on the ability of state making elites to make war, which depends upon the ability to extract resources from the population through an effective bureaucracy. See Charles Tilly, "Reflections on the History of European State-Making," in Charles Tilly, ed., The Formation of National States in Western Europe (Princeton: Princeton University Press, 1975), pp. 3-83.

24. Max Weber, "Politics as Vocation" in H. Gerth and C. Wright Mills eds., For Max Weber: Essays in Sociology (New York: Oxford University Press, 1958), pp. 77-128.

25. "Organized criminals" and "insurgents" should, of course, be understood as ideal types - that is, abstract models that identify and exaggerate certain essential characteristics of a given phenomenon in order to facilitate the identification of commonalities and differences between phenomena. Max Weber, The Methodology of the Social Sciences, Edward Shils and Henry Finch, eds. (New York: Free Press), pp. 90-110.

26. In 2004 the PWG and MCC merged to form the CPI (Maoist).

27. CPI (Maoist), "CPI Maoist Programme”; CPI (Maoist), "Strategy and Tactics of the Indian Revolution," (Central Committee [Provisional] pamphlet (September 21, 2004).

28. Bela Bhatia, "The Naxalite Movement in Central Bihar," Economic and Political Weekly Vol. 40, No. 15 (April, 2005), pp. 1536-49; K Balagopal, "Maoist Movement in Andhra Pradesh," Economic and Political Weekly Vol. 41, No. 29 (July, 2006), pp. 3183-87; Nandini Sundar, "Bastar, Maoism and Salwa Judum," Economic and Political Weekly Vol. 41, No. 29 (July, 2006), pp. 3187-92; George Kunnath, "Becoming a Naxalite in Rural Bihar: Class Struggle and its Contradictions," Journal of Peasant Studies Vol. 33, No. 1, (August, 2006), pp. 89-123; Roy, "Walking With The Comrades." Gautam Navlakha, "Days and Nights in the Maoist Heartland," Economic and Political Weekly Vol. 45, No. 16 (April, 2010), pp. 38-47.

29. Member of dalams live within the community and undertake non-violent activities, including the political education of the local population and the provision of various public goods. In addition to the collective benefits that are typical of left wing insurgent organizations-such as land reforms, wages increases, and better prices for agricultural produce-sanghams promote issues such as women's rights and tribal languages and literature.

30. Mao Tse-Tung, On Guerrilla Warfare (Translated by Samuel Griffith) (New York: Praeger, 1961); Kalyvas, Logic of Violence; Jeremy Weinstein, Inside Rebellion: The Politics of Insurgent Violence (Cambridge: Cambridge University, 2007).

31. Azad, "Maoists in India: A Rejoinder," Economic and Political Weekly Vol. 41, No. 41 (July, 2006), p. 4381.

32. Max Weber, From Max Weber: Essays in Sociology, (Hans Gerth and C. Wright Mills, eds. (New York: Oxford University Press, 1946), p. 79.

33. Manoranjan Mohanty Revolutionary Violence: A Study of the Maoist Movement in India (New Delhi: Sterling, 1977); Bhatia, "Naxalite Movement"; Ramachandra Guha, "Adivasis, Naxalites and Indian Democracy," Economic and Political Weekly, Vol. 42, No. 32 (August, 2007), pp. 3305-12; Balagopal, "Maoist Movement"; Kunnath, "Becoming a Naxalite"; Ministry of Tribal Affairs, National Tribal Policy: 
A Policy for the Scheduled Tribes of India (New Delhi: Official Documents Section in the Library of the Central Secretariat (Shastri Bhawan), 2006); Planning Commission of India, Development Challenges in Extremist Affected Areas: Report of an Expert Group (New Delhi: Government of India, 2008); Sumanta. Banerjee, India's Simmering Revolution: The Naxalite Uprising (New Delhi: Zed Books, 2008 [1984]); Ministry of Home Affairs, Annual Report 2009-10 (New Delhi: Official Documents Section in the Library of the Central Secretariat (Shastri Bhawan), 2010); Kennedy and Purushotham "Beyond Naxalbari"; Kennedy and King "Adivasis, Maoists and Insurgents." Shah argues the insurgents have "little commitment to ... land redistribution and better terms for sharecroppers, a minimum wage, access to common property resources, basic social rights and respect for lower castes.” Shah, "Markets of Protection,” p. 303. It should be noted that this statement contradicts almost every other analysis of the insurgency. As John Harriss points out: "The few ethnographic studies that there are strongly confirm these general arguments about the extent to which the Naxalites win support among, and articulate the needs and aspirations of poor and landless peasants and adivasis." John Harriss, "What is Going on in India's 'Red Corridor'? Questions About India’s Maoist Insurgency,” Pacific Affairs, Vol. 84, No. 2 (June, 2011), p. 319.

34. Max Weber, Political Writings, Peter Lassman and Ronald Spiers, eds. (Cambridge, UK: Cambridge University Press, 1994), p. 310. Similarly, Mao famously states that political power grows out of the barrel of a gun.

35. Prakash Singh, “The Trajectory of the Movement,” in P.V. Rama, The Naxal Challenge: Causes, Linkages, and Policy Options (New Delhi: Pearson, 2008), p. 10.

36. Law Kumar Mishra, "Naxalites Gun Down Three Youths in "Public Court,” Times of India, December 13, 2001, p. 1.

37. "Naxals Behead Police Informer," Times of India, August 5, 1990; "Maoists Behead Former Comrade in H”bag," Times of India, August 10, 2009.

38. "Naxalites Chop Off Teacher's Hand," Times of India, December 21, 1982; "Naxals in Gadchiroli Kill a Suspected Police Informer," Times of India, July 18, 1998.

39. Bhatia, "Naxalite Movement"; Balagopal, "Maoist Movement"; Sundar, "Bastar, Maoism and Salwa Judum."

40. "Maoists on Hunt for Police Informers," Times of India, May 8, 2010.

41. "Villagers Bear Brunt of Anti-Red Ops," Times of India, September 30, 2011.

42. Kalyvas, The Logic of Violence.

43. Ganapathy, “Open Reply to Independent Citizen's Initiative on Dantewada," Economic and Political Weekly Vol. 42, No. 1 (January, 2007), pp. 68-69.

44. Shah, "Markets of Protection," p. 299.

45. Pushpa Iyengar, “Naxal Guns Down Own “Dalam” Members, Qualifies for Reward,” Times of India, April 11, 1998, p. 7. The value of the rupee has fluctuated over the past 25 years but throughout this article we use an exchange rate of 50 rupees to the dollar.

46. "These Naxals kill comrades to earn govt. cash awards," Times of India, April 15, 1998.

47. K. Balchand, "Maoists must Apologize for Niyamat Murder," The Hindu November 13, 2011.

48. Manohar Lal, "Spurned in Love, Rebel Leader Kills Techie,” Times of India, April 27, 2011.

49. Neelesh Misra, “Talking Revolution,” Hindustan Times, March 15, 2008.

50. Mohua Chatterjee, "Maoists Apologize for Slaying Villager in Jharkhand," Times of India September 18, 2011.

51. Ganapathy, “Open Reply,” p. 68. Also, see Navlakha's interview with Ganapathy and Shah's interview with Jharkhand leader Gopalji. Navlakha, "Days and Nights."

52. Independent Citizens' Initiative, "War in the Heart of India: An Enquiry into the ground Situation in Dantewara District, Chhattisgarh” (2006). Accessed July 15, 2010 via cpjc.files.wordpress.com; Kennedy and King, "Understanding the Conviction of Binayak Sen"; Kennedy and Purushotham, "Beyond Naxalbari”; Kennedy and King, "Adivasis, Maoists and Insurgency in India."

53. Supriya Sharma, "Security Forces Running Riot in Dantewada?” Times of India, March 23, 2011.

54. Aman Sethi, "A Chaotic Operation Leaves Many Questions Unanswered," The Hindu, June 30, 2012.

55. Kalyvas, The Logic of Violence.

56. “Reds Extort Rs 2k cr Each Year in India: C”garh DGP,” Times of India, November 29, 2009.

57. Rajaram Satapathy, Sanjay Ojha, and Caesar Mandal, “The Maoist Empire: Rs 1,500cr and Counting,” Times of India, April 11, 2010.

58. Sanjay Ojha, "Maoists loot Rs 5 Crore from Bank Van in Ranchi,” Times of India, May 22, 2008.

59. Supriya Sharma, "Big business paying Maoists is condemnable: Chidambaram," Times of India, November 15, 2011.

60. Tusha Mittal, “I Am the Real Desh Bhakt,” Tehelka Vol. 6, No. 46 (November, 2009).

61. Subodh Varma, "How a People’s War Left the People Behind,” Times of India, October 3, 2009.

62. "Landlords Turn to Naxals for Protection," Times of India, January 12, 1988, p. 17.

63. See Suykens, "Diffuse Authority."

64. Supriya Sharma, “Tendu Leaves Little Hope for tribals,” Times of India, June 13, 2011.

65. Shashwat Gupta Ray, "Teakwood Smuggling Destroying the Forest to Save It," Tehelka, February 24, 2007; "Hemp Worth Over $10 \mathrm{cr}$ Destroyed in Rayagada," Times of India, December 16, 2011; Pradeep Thakur, 
“Illegal Opium Trade Could Be Funding Maoists," Times of India, June 22, 2009; "Naxals Cultivating Poppy for funds," Times of India, March 29, 2010.

66. Shah, "Markets of Protection."

67. Kashi Prasad, “Maoists Abduct Six Guards Over Payment of Levy,” Times of India, September 3, 2009.

68. Supriya Sharma, "Industry Meets Insurgency," Times of India, October 9, 2011.

69. S. K. Sirendran, “Gadchiroli Naxals Have Tribals in Thrall,” Times of India, October 6, 1992, p. 7.

70. Sirendran, "Gadchiroli Naxals."

71. Jonathan Kennedy “The Socioeconomic Determinants of Natural Resource Conflict: Minerals and Maoist Insurgency in India," forthcoming in Society and Natural Resources.

72. Avijit Ghosh, “Red Mist Over Bailadila’s Mining Townships,” Times of India, April 11, 2010.

73. "Essar Pays Protection Money to Maoists in Chhattisgarh: WikiLeaks," Times of India, September 6, 2011.

74. "Essar Pays Protection Money," Times of India.

75. See Jonathan Kennedy, The Political Economy of Conflict between Dominant Societies and Indigenous Communities: Adivasis, Maoist Insurgents and the State in the Central Indian Tribal Belt, (PhD Thesis: University of Cambridge, 2013), chapter 4.

76. Mittal, "I Am the Real Desh Bhakt."

77. Reno, “Shadow States," p. 45.

78. Max Weber, The Protestant Ethic and the Spirit of Capitalism (translated by Talcott Parsons) (London: Routledge, 1993 [1920]), pp. xxxvii-xxxviii).

79. Misra, “Talking Revolution.”

80. Shah, "Markets of Protection."

81. See, for example, Akhil Gupta, "Blurred Boundaries: The Discourse of Corruption, the Culture of Politics, and the Imagined State," American Ethnologist Vol. 22, No. 2 (May, 1995), pp. 375-402.

82. "Maoist Cadres Kill Former Colleague," Times of India, July 5, 2010.

83. "Encounter Claims One,” Times of India, September 24, 2011.

84. "Ex-Maoist Held for Extorting Money from Govt Officials," Times of India, August 18, 2011.

85. "Fake-Maoist Gang Busted in Rayagada," Times of India, March 30, 2011.

86. "Youth Held for Posing as Red rebel, Extorting Money," Times of India, May 13, 2011.

87. “12 "Fake” Maoists Caught with Arms," Times of India, November 13, 2011.

88. Rahul Pandita, Hello Bastar: The Untold Story of India's Maoist Movement (Tranquebar: Chennai, 2011).

89. Mohanty Revolutionary Violence; Banerjee India's Simmering Revolution.

90. "No Evidence of China Supporting Maoists: Chidambaram,” Times of India, August 11, 2010.

91. “ISI Using D-gang to Befriend Naxals,” Times of India, August 14, 2010.

92. CPI (Maoist), "Interview with Comrade Azad, spokesperson of the CC, CPI (Maoist) on the Present Developments in Nepal," Maoist Information Bulletin 2, May 10, 2008, pp. 1-6.

93. Rahul Pandita, "We Shall Certainly Defeat the Government," Open Magazine, October 17, 2009.

94. VR Mani, “LTTE Aiding Naxals: BJP,” Times of India, July 24, 1990, p. 1; “LTTE training PWG Naxels," Times of India, July 2, 1993, p. 4; S. Balakrishnan, "PWG Resurgence in Bastar," Times of India, December 5,1993 , p. 9.

95. "Arms Factory in M.P. Raided,” Times of India, April 14, 1993, p. 12; “CRPF Raid Reveals Maoists Have Tech to Clone AK-47s," Times of India, January 20, 2010.

96. Bisheshwar Mishra, "Centre Set to Probe LTTE-Naxal Links," Times of India, June 11, 2000, p. 8.

97. CPI (Maoist), “A Decade March of People’s Liberation Guerilla Army in the Path of People’s War (20002010),” (Central Committee Document, 2010).

98. “Naxalites Attack Koraput Town, Loot Police Stations,” Times of India, February 7, 2004.

99. Ghosh, "Red Mist Over Bailadila."

100. Ashutosh Mishra and Subhashish Mohanty, "Panel Moots Armourer Cadre," The Telegraph (Calcutta), March 24, 2012.

101. "Maoists run amok in Koraput," The Hindu, June 26, 2009.

102. Max Weber, Economy and Society: An Outline of Interpretive Sociology, Guenther Roth and Claus Wittich, eds. (New York: Bedminster Press, 1968), pp. 324-73.

103. Thomas Blom Hansen and Finn Stepputat, "Sovereignty Revisited," Annual Review of Anthropology, 35 (October, 2006), p. 297.

104. Jackson, Quasi-States; Ruggie, “Territoriality and Beyond”; Reno, Warlord Politics; Daron Acemoglu, Simon Johnson, and James Robinson, "The Colonial Origins of Comparative Development: An Empirical Investigation," American Economic Review Vol. 91 No. 5, (December, 2001), pp. 1369-1401; Mahmood Mamdani, When Victims Become Killers: Colonialism, Nativism, and the Genocide in Rwanda, (Princeton: Princeton University Press, 2002); Hansen and Stepputat, "Sovereignty Revisited."

105. Mann, "The Autonomous Power of the State."

106. Hansen and Stepputat, "Sovereignty Revisited," p. 297.

107. Robert Jackson, Quasi-States: Sovereignty, International Relations and the Third World (Cambridge University Press: Cambridge, 1991); John Ruggie, “Territoriality and Beyond: Problematizing Modernity in International Relations," International Organization Vol. 47, No. 1 (Winter, 1993), pp. 139-74; Reno, Warlord Politics. 
108. Jackson, Quasi-States.

109. Atul Kohli, Democracy and Discontent: India's Growing Crisis of Governability. (Cambridge: Cambridge University Press, 1990).

110. "Caste Feuds Spur Bihar Naxalites," Times of India, January 1, 1988, p. 17; "Landlords Turn to Naxals for Protection," Times of India, January 12, 1988, p. 17; Bhatia, “The Naxalite Movement”; Kunnath, "Becoming a Naxalite."

111. Nandini Sundar, Subalterns and Sovereigns: An Antbropological History of Bastar, 1854-2006 (Oxford: Oxford University Press, 2007); Felix Padel, Sacrificing People: Invasions of a Tribal Landscape (New Delhi: Orient Blackswan, 2009).

112. MN Srinivas, “The Social System of a Mysore Village," in McKim Marriot, Village India: Studies in the Little Community (Chicago: University of Chicago Press, 1955), pp. 1-35; Kohli, Democracy and Discontent; Ramachandra Guha, India After Gandhi: The History of the World's Largest Democracy (Picador: London, 2007).

113. Suykens, "Diffuse Authority,” p. 158.

114. Shah, "Markets of Protection," pp. 300, 305.

115. Reno, "Shadow States," p. 46.

116. Tilly, From Mobilization to Revolution.

117. Kalyvas, Logic of Violence.

118. Throughout India Republic Day and Independence Day are celebrated in government institutions such as schools with flag hoisting ceremonies.

119. “Tribals, Maoists Hoist Black Flags in Lalgarh,” Times of India, August 15, 2009; "Maoists Hoist Black Flags at Several Places in Bihar," Times of India, January 26, 2011; Debabrata Mohanty, "Meanwhile, black flags in Maoist areas in Orissa," Indian Express, August 16, 2010.

120. Rajaram Satapathy, "Ministers Airlifted to Maoist Areas for Republic Day,” Times of India, January 25, 2011.

121. Alok Chamaria, “Cops Unfurl Tricolour in Red Den,” Times of India, January 27, 2011.

122. Ministry of Home Affairs, Annual Report 2004-05 (Official Documents Section in the Library of the Central Secretariat (Shastri Bhawan), New Delhi, 2005), p. 44.

123. Navlakha, "Days and Nights"; Shubhranshu Choudhary, Let's Call Him Vasu: With the Maoists in Chbattisgarb (New Delhi: Penguin, 2012).

124. "Heart of Maoist Land is No-Go Area for Politicians," Hindustan Times, April 10, 2009.

125. Soumittra Bose, “Naxals Rule the Roost as Cops Take It Easy,” Times of India, June 22, 2011.

126. A First Information Report (or FIR) is a written document prepared by police when they receive information about an alleged offence.

127. Supriya Sharma, "Law of the jungle," Times of India, April 24, 2011.

128. Bhatia, "The Naxalite Movement"; Kunnath, "Becoming a Naxalite."

129. Balagopal, "Maoist Movement."

130. Sukumar Mahato and Arnab Ganguly, "With Locals on Their Side, Maoists Now Striking at Will,” Times of India, February 17, 2010; John Harriss, “What is Going on in India's 'Red Corridor'?”

131. Supriya Sharma, "Charge of a Light and Lonely Brigade,” Times of India, August 28, 2011.

132. Nitin Mahajan, "12 Policemen Feared Dead in Chhattisgarh Naxal Attack,” Indian Express, December 21, 2007.

133. Rajaram Satapathy, "Fear of Naxal Attack Grips Policemen in Two Orissa Districts," Times of India, December 3, 2002, p. 10.

134. Satapathy, "Fear of Naxal Attack."

135. Mahato and Ganguly, "With Locals on Their Side."

136. "War Against Naxals that Backfired," Times of India, September 24, 2005.

137. Bela Bhatia, "Jailbreak and the Maoist Movement," Economic and Political Weekly Vol. 40, No. 51, (December, 2006), pp. 5369-71.

138. “Naxals Attack Orissa Jail, Free Inmates,” Times of India, March 24, 2006.

139. Amitabh Tiwari, "Chhattisgarh Jailbreak: 110 Maoists Escape," Times of India, December 17, 2007.

140. K. Srinivas Reddy, "Maoists Attack Police, Free Top Leader from Court Premises,” The Hindu, June 24, 2009.

141. Prakash Singh, The Naxalite Movement in India (New Delhi: Rupa, 1996).

142. "I am Tired and Need Some Rest, Freed Italian Paolo Bosusco Says," Times of India, April 12, 2012.

143. Saytanarayan Pattnaik, "Ganti Vows to Work for Release of Tribals," Times of India, July 2, 2011.

144. Mahato and Ganguly, "With Locals on Their Side."

145. Ajay Kumar, “A Slap in Face of NTR Govt,” Times of India, January 1, 1988, p. 9.

146. Sanjay Ojha, "Reds Call Shots in "Liberated” Zones: Jairam Ramesh,” Times of India, December 4, 2011.

147. Planning Commission of India, Development Challenges.

148. John Harriss, “What is Going on in India's 'Red Corridor'?”

149. Shah, "Markets of Protection," p. 310; Suykens, "Diffuse Authority,” p. 158.

150. "Reds Running Parallel Admn: State YC Chief,” Times of India, December 20, 2011.

151. Vishwa Mohan, "Are Maoists Backing Rural Job Scheme?” Times of India, April 14, 2010. 


\section{India Review}

152. CPI (Maoist), "Parliament is an Instrument of Oppression and Terror in the Hands of the Reactionary Ruling Classes!" (Central Committee Press Statement, April 2, 2009).

153. "Vote at Your Own Peril, says Maoists," Times of India, December 8, 2009.

154. "Heart of Maoist Land," Hindustan Times.

155. "Heart of Maoist Land," Hindustan Times.

156. "Red Fear Looms Large Over Politicians,” Times of India, December 5, 2009.

157. "Five Election Officials Among 17 Killed in Naxal Attacks," Indian Express, October 16, 2009.

158. Supriya Sharma, “Zero Voting Marks Elections in Chhattisgarh's Maoist Heartland,” Times of India, May 9, 2011.

159. “States within the State,” Times of India, January 16, 2010.

160. Bose, "Naxals Rule the Roost."

161. Pandita, Hello Bastar.

162. Suneet Vir Singh and Sumita Dasgupta, “TDP's Nexus with Naxalites Alleged,” Times of India, June 4, 1991, p. 9.

163. Uttam Sengupta, “Comrades Turn Gangsters, and Fight for Turf,” Times of India, September 18, 1997, p. 13; "RJD Accused of Conniving with Naxals," Times of India, April 29, 2004.

164. Sonali Das, "Did Maoists Tip Scales in Favor of Proxies?” Times of India, December 24, 2009.

165. “Thin Line Between Maoists \& Politicians in State: Ramesh,” Times of India, February 15, 2012.

166. Soumittra Bose, "Have the Maoists Rigged G”chiroli GP Elections?” Times of India, April 24, 2010.

167. Soumittra Bose, "Naxal Kangaroo Court in Gadchiroli Under Cops" Noses," Times of India, May 21, 2012.

168. Jeffrey Herbst, States and Power in Africa: Comparative Lessons in Authority and Control (Princeton: Princeton University Press, 2000), p. 5.

169. Reno, "Shadow States," p. 44.

170. Reno, "Shadow States," p. 44.

171. Shah, "Markets of Protection," p. 298.

172. “Naxalism Graver Threat Than Jihadi Terror: PC,” Times of India, March 13, 2010. 